\title{
Peningkatan Kapasitas Masyarakat dalam Pengelolaan Sampah Secara Mandiri dan Pemetaan Sosial
}

\author{
Oleh: \\ Sahadi Humaedi ${ }^{1}$, Yulinda Adharani ${ }^{2}$, Yusshy Kurnia Herliani ${ }^{3}$ \\ 1. Dosen IImu Kesejahteraan Sosial, Fakultas IImu Sosial Dan IImu Politik, Universitas Padjadjaran \\ 2. Dosen Fakultas Hukum, Universitas Padjadajran \\ 3. Dosen Fakultas Keperawatan, Universitas Padjadjaran \\ Email \\ sahadi.humaedi@unpad.ac.id,yulinda.adharani@unpad.ac.id,yusshy.kurnia@unpad.ac.id
}

\begin{abstract}
ABSTRAK
Artikel ini, berisi tentang kegiatan peningkatan kapasitas masyarakat dalam pengelolaan sampah secara mandiri dan pemetaan sosial yang dilakukan di wilayah RW 01 Desa J atiroke, Kecamatan J atinangor, Kabupaten Sumedang. Latar belakang ditulisnya karya ini karena adanya permasalahan sampah di lingkungan RW 01 Desa Jatiroke, Kecamatan Jatinangor Kabupaten Sumedang. Tujuan jangka pendek diadakannya kegiatan ini adalah mampu memberikan pengetahuan dan keterampilan kepada khalayak sasaran tersebut mengenai pengelolaan sampah secara mandiri. Sementara tujuan jangka panjangnya adalah merubah pola dan perilaku masyarakat untuk lebih peduli terhadap lingkungan sekitar. Pada kegiatan ini, terdapat dua kegiatan besar yaitu kegiatan peningkatan kapasitas masyarakat dan kegiatan pemetaan social. Kegiatan peningkatan kapasitas masyarakat dalam pengelolaan sampah secara mandiri dilaksanakan dengan berbagai kegiatan pelatihan yang mendukung pengelolaan sampah secara mandiri. Kegiatan pelatihan ini dipandu oleh narasumber (tenaga ahli) sebagai fasilitator dan dibantu dengan seperangkat alat untuk melakukan simulasi atau praktik secara langsung. Sementara kegiatan pemetaan sosial akan dilaksanakan dengan pendekatan partisipatif dengan tetap memperhatikan kaidah-kaidah kaji-tindak. Dengan adanya kegiatan ini, diharapkan dapat meningkatkan kemampuan kelompok sasaran dalam mengelola sampah secara organik dan diharapkan pula dapat menjadi agen perubahan dalam masyarakat.
\end{abstract}

Kata Kunci: Sampah, Peningkatan Kapasitas, Pemetaan Sosial

\section{ABSTRACT}

This paper contains about the activities in order to build the community capacity in terms of waste management independently as well as social mapping activities that conducted at RW 01 on Jatiroke Village in Jatinangor, Sumedang. The background of this writing is because of the problems caused by waste in the environment. The short-term goal of the activity is to provide them a specific knowledge as well as skills so they can manage their waste independently. In the meantime, the expected long-term goal is to change the pattern and behavior of the community, so that they are more concerned about the surrounding environtment. During the activities in the village, there were two main activities that have been done. The first is community capacity building, and the second is social mapping. The community capacity building was implemented with various training which supports the waste management independently. The training is guided by experts as facilitators and also supported by a set of tools for simulation directly. Meanwhile, for social mapping, a participatory approach is taken with due regard to the rules of study and action. The implementation of such activities is hopefully can improve the ability of each target group in managing the organic waste, and then hopefully they have the ability to be agents of change in their society.

Keywords: Waste, Capacity Building, Social Mapping 


\section{Pendahuluan}

Pada tahun akademik 2016/2017 yang lalu Universitas Padjadjaran telah menyelenggarakan kegiatan perkuliahan TPB (Tahap Persiapan Bersama), salah satu Mata Kuliah dalam TPB ini adalah Mata Kuliah Olahraga, Kesenian dan Kreatifitas. Penyelenggaraan kuliah ini dimaksudkan untuk memperkenalkan Olah-raga, kesenian, kreativitas sebagai media dalam mengintegrasikan berbagai keterampilan dasar yang perlu dikuasai mahasiswa dalam kaitannya dengan penumbuhan Pola Ilmiah Pokok Universitas Padjadjaran yakni Bina Mulia Hukum dan Lingkungan Hidup.

Dalam pelaksanaannya ditekankan pada penanaman karakter dasar leadership yang dimulai untuk saling mengenal, membangun relasi interpersonal, membangun kerjasama tim yang dalam prosesnya juga dibangun untuk mampu mengenali lingkungan sekitarnya dengan eksplorasi, konsolidasi dan tindak lanjut melalui beragam kegiatan kreatif berbasis olah raga dan kesenian untuk pengembangan karakter mahasiswa Unpad. Mata Kuliah OKK mengusung Konsep: Menggagas kerja, mencipta masa depan desa di kecamatan Jatinangor, Kabupaten Sumedang, dengan tujuan : Menjalin tali silaturahmi yang erat antara warga Unpad umumnya, dan khususnya Mahasiswa Baru Tahun 2016 dengan warga desa-desa di Jatinangor, menggali pengetahuan tentang kehidupan masyarakat pedesaan yang berada di tengah keragaman budaya, sosial, dan ekonomi.

Saat ini kegiatan Mata Kuliah OKK khususnya di RW 01 Desa Jatiroke telah dilaksanakan, dan berdasarkan dari hasil observasi dan pemetaan wilayah menunjukan adanya kebutuhan masyarakat terkait dengan pengelolaan sampah secara mandiri guna menanggulangi persoalan sampah yang bersumber dari rumah tangga. Merujuk pada kondisi tersebut di Desa Jatiroke khususnya pada RW 01, kami tim OKK dari RW 01 Desa Jatiroke bermaksud menindaklanjuti kegiatan OKK yang telah dilaksankan tersebut dengan kegiatan Pengabdian Pada Masyarakat Prioritas pada tahun 2017 ini. Kegiatan akan diarahkan pada peningkatan kemampuan masyarakat dalam mengelola sampah secara mandiri khususnya di lingkungan RW 01 Desa Jatiroke.

\section{Metode}

Kegiatan Penguatan Kapasitas Masyarakat Dalam Pengelolaan Sampah Secara Mandiri Dan Pemetaan Sosial Di Lingkungan RW 01 Desa Jatiroke, Kec. Jatinangor, Kab. Sumedang ini akan dilaksanakan dengan berbagai kegiatan pelatihan yang mendukung pengelolaan sampah secara mandiri, Kegiatan pelatihan ini akan dipandu oleh narasumber (tenaga ahli) sebagai fasilitator dan dibantu dengan seperangkat alat untuk melakukan simulasi atau praktik secara langsung. Sebelum kegiatan pelatihan dilakukan terdapat beberapa hal kegiatan berupa persiapan yang perlu dilakukan, kemudian melakukan evaluasi kegiatan pelatihan maupun evaluasi secara keseluruhan yang dilakukan pasca pelatihan, selain itu akan dilakukan pula pemetaan social berupa kaji tindak dengan pendekatan partasipatif. Sehingga denga adanya kegiatan pemetaan social secara partisipatif ini dapat tergambarkan secara detail persoalan, potensi serta kebutuhan masyarakat yang berada di RW 01 Desa Jatiroke guna ditindaklanjuti pada tahun berikutnya. Berikut adalah rincian kegiatannya pada tabel di bawah ini : 


\begin{tabular}{|c|c|c|c|c|}
\hline $\begin{array}{c}\text { Jurnal Penelitian \& } \\
\text { PPM }\end{array}$ & ISSN: 2442-448X & Vol 5, No: 1 & Hal: $1-110$ & April 2018 \\
\hline
\end{tabular}

\section{Pembahasan}

\section{Proses Pelatihan}

Pada proses pelatihan ini, dilakukan

beberapa kegiatan diantaranya:

Tabel 1

Tahapan Kegiatan PPMP OKK

\begin{tabular}{|c|l|l|l|l|}
\hline \multirow{2}{*}{ No. } & \multirow{2}{*}{ Rencana Kegiatan } & \multicolumn{1}{|c|}{ Keterlibatan dalam Kegiatan } \\
\cline { 3 - 5 } & $\begin{array}{c}\text { Persiapan kegiatan } \\
\text { PPM }\end{array}$ & $\begin{array}{l}\text { Membuat proposal dan } \\
\text { mencari data awal } \\
\text { wilayah }\end{array}$ & $\begin{array}{l}\text { Mersama dosen ke } \\
\text { lapangan melakukan re- } \\
\text { assessment }\end{array}$ & Sebagai narasumber \\
\hline 2. & Pemetaan wilayah & $\begin{array}{l}\text { Mempelajari secara } \\
\text { lebih mendalam } \\
\text { mengenai potensi- } \\
\text { potensi di Desa Jatiroke, } \\
\text { yaitu potensi yang dapat } \\
\text { dimanfaatkan dalam } \\
\text { kegiatan PPM ini. }\end{array}$ & $\begin{array}{l}\text { Tenaga lapangan } \\
\text { pelaksana pemetaan }\end{array}$ & Narasumber \\
\hline 3. & $\begin{array}{l}\text { Pelaksanaan } \\
\text { pelatihan }\end{array}$ & $\begin{array}{l}\text { Melaksanakan proses } \\
\text { pelatihan }\end{array}$ & $\begin{array}{l}\text { Membantu proses } \\
\text { administrasi dan proses } \\
\text { pelaksanaan pelatihan }\end{array}$ & $\begin{array}{l}\text { Menjadi peserta } \\
\text { pelatihan }\end{array}$ \\
\hline 4. & $\begin{array}{l}\text { Monitoring dan } \\
\text { evaluasi }\end{array}$ & $\begin{array}{l}\text { Melakukan pengkajian } \\
\text { dan pengukuran } \\
\text { keberhasilan dari } \\
\text { pelatihan }\end{array}$ & $\begin{array}{l}\text { Mengumpulkan } \\
\text { informasi } \\
\text { kebermanfaatan } \\
\text { pelatihan }\end{array}$ & $\begin{array}{l}\text { Memberikan } \\
\text { penjelasan } \\
\text { mengenai } \\
\text { kebermanfaatan } \\
\text { pelatihan }\end{array}$ \\
\hline
\end{tabular}

Sumber : Penelitian 2018

\section{Persiapan Pelatihan}

Persiapan pelatihan komposter dimulai dengan mencari narasumber dan narasumber menyiapkan materi untuk pelatihan. Setelah narasumber telah dapat, maka dilakukan pendataan terhadap masyarakat yang akan mengikuti pelatihan, kemudian menghubungi orang-orang yang telah didata tersebut. Selanjutnya menentukan hari dan tanggal serta tempat pelatihan. Kemudian persiapan pemesanan snack dan makanan berat bagi peserta yang mengikuti pelatihan, serta persiapan alat tulis dan pembuatan spanduk. Setelah semua persiapan tersebut selesai, maka dilaksanakanlah pelatihan komposter.

\section{Waktu dan Tempat Pelatihan}

Pelatihan komposter ini dilaksanakan pada hari kamis tanggal 26 Oktober 2017, bertempat di balai desa Jatiroke. Pelatihan komposter ini dilaksanakan dalam dua sesi. Sesi pertama ini dilaksanakan mulai dari pukul 09.00 WIB sampai dengan pukul 12.00 WIB. Kegiatan pelatihan ini diawali dengan pembukaan oleh Pak Sahadi selaku utusan dari pihak UNPAD dan Pak Kuwu selaku utusan dari pihak desa. Kemudian, dilakukan pretest tentang pengetahuan masyarakat Desa Jatiroke tentang sampah. Setelah hasil pretest dikumpulkan, lalu narasumber memberikan materi tentang sampah dan cara pengelolaannya. Narasumber juga mengajarkan dan mempraktikkan bersama-sama dengan peserta pelatihan bagaimana cara 
mengelola sampah non organik, salah satunya yaitu dengan cara membuat kerajinan tangan berupa keranjang belanja dari gelas minuman bekas. Selajutnya, waktu untuk istirahat, shalat dan makan bagi peserta pelatihan komposter.

Sesi kedua dilaksanakan dari pukul 13.

00 WIB sampai dengan pukul 16.00 WIB, dimulai dengan pemberian materi dari narasumber tentang komposter. Lalu narasumber mempraktikkan kepada peserta pelatihan, bagaimana cara membuat dan mengolah sampah menjadi kompos dengan menggunakan komposter. Selanjutnya dilakukan posttest tentang pengetahuan masyarakat setelah diberikan materi dari narasumber. Setelah hasil posttest dikumpulkan, dilaksanakan serah terima alat komposter dari pihak UNPAD kepada pihak desa yang dimulai dari RW 01 sampai RW 05. Kemudian dilakukan serah terima komposter, dilakukan foto bersama antara pihak UNPAD dan pihak desa. Dengan dilakukan foto bersama tersebut, maka berakhirlah acara pelatihan komposter yang dilaksanakan di Desa Jatiroke.

\section{Peserta Pelatihan}

Peserta pelatihan ini, dihadiri oleh pihak UNPAD dan pihak desa. Dari pihak UNPAD sendiri dihadiri oleh dosen pembimbing dan para fasil OKK. Sedangkan dari pihak desa dihadiri oleh para ketua RW dan ketua RT, ibu PKK, karang taruna, dan masyarakat desa Jatiroke. Dari kegiatan ini, peserta pelatihan sangat antusias mengikuti pelatihan yang diberikan oleh narasumber, terutama saat pembuatan kerajinan tangan dan praktik penggunaan komposter.

\section{Kondisi Kelompok Sasaran Sebelum Pelatihan}

Kondisi peserta pelatihan, khususnya pengetahuan tentang sampah masih rendah. Hal ini terbukti dengan banyaknya peserta yang mengaku tidak mengetahui tentang sampah itu sendiri dan jenis-jenisnya. Umumnya, jenis sampah yang diketahui oleh peserta pelatihan hanya sampah organic dan non-organik. Selain kurangnya pengetahuan tentang sampah, peserta pelatihan juga kurang tahu cara mengolah dan memanfaatkan sampah tersebut. Hal ini disebabkan karena kurangnya pelatihan dan penyuluhan tentang pengolahan sampah. Bahkan, banyak peserta yang mengaku belum pernah mengikuti pelatihan pengolahan sampah. Biasanya pengolahan sampah di wilayah Desa Jatiroke hanya dilakukan dengan cara membakar sampah tersebut.

\section{Kondisi Kelompok Sasaran Sesudah Pelatihan}

Setelah dilakukan pelatihan tentang sampah dan cara pengolahannya, pengetahuan peserta pelatihan tentang sampah semakin bertambah dan terjadi peningkatan. Peserta juga mengetahui, bahwa jenis-jenis sampah tidak hanya sampah organik dan non-organik, melainkan juga ada sampah B3 dan residu. Selain pengetahuan tentang jenis sampah, peserta juga mendapatkan pengetahuan tentang cara pengolahan sampah. Seperti sampah organic bisa dijadikan kompos, dan sampah nonorganik bisa dibuat kerajinan tangan, seperti keranjang dari bekas gelas minuman. Para peserta pelatihan juga memahami bahwa sampah ini juga bisa menghasilkan uang, misalkan adanya bank sampah sebagai tempat menukar sampah dengan uang, dimana bank sampah ini berupaya memaksimalkan nilai sampah dengan pengelolaan sampah secara bijak.

\section{Simpulan}

Pada penulisan karya tulis ini terdapat dua kegiatan yaitu kegiatan peningkatan kapasitas masyarakat dan kegiatan pemetaan social. Kegiatan peningkatan kapasitas masyarakat dalam pengelolaan sampah secara mandiri dilaksanakan dengan berbagai kegiatan pelatihan yang mendukung pengelolaan sampah secara mandiri, salah satunya dengan pelatihan 
komposter. Pelatihan komposter yang dilaksanakan di balai Desa Jatiroke pada hari kamis tanggal 26 Oktober 2017 diikuti oleh dosen pembimbing dan fasil OKK selaku pihak dari UNPAD dan para ketua RT dan RW, Ibu PKK, karang taruna serta masyarakat Desa Jatiroke. Pada kegiatan ini, dilakukan pelatihan tentang sampah dan cara pengelolaannya. Peserta yang tadi awalnya tidak tahu apa itu sampah dan bagaimana cara pengelolannya, akhirnya menjadi tahu. Peserta juga tahu bagaimana cara menggunakan dan mengelola alat komposter sebagai alat untuk mengatasi masalah sampah organik. Selain itu, peserta juga mengetahui bagaimana cara memanfaatkan sampah non-organik. Pada pelatihan ini, terjadi peningkatan pengetahuan peserta akan sampah dan cara pengelolaan sampah tersebut. Sementara kegiatan pemetaan sosial akan dilaksanakan dengan pendekatan partasipatif dengan tetap memperhatikan kaidah-kaidah kaji-tindak.

\section{Daftar Pustaka}

Adi.Isbandi Rukminto. 2008. Intervensi Komunitas Pengembangan Masyarakat Sebagai Upaya Pemberdayaan Masyarakat. Jakarta: Rajawali Pers

Cary, Lee. 1970. Community Development As A Process. Missouri. Univerity of Missouri Press.

Hikmat, Harry. 2006. Strategi Pemberdayaan Masyarakat. Bandung : Humaniora Utama Press.

Ife, Jim. 2008. Community Development : Alternatif Pengembangan Masyarakat di Era Globalisasi. Jogjakarta. Pustaka Pelajar.

Kartasasmita, Ginandjar. 1996. Pembangunan untuk rakyat: memadukan pertumbuhan dan pemerataan. Jakarta. CIDES
Lewis, Judith A., 1991, Management of Human Services Programs. California Brooks/Cole Publishing Company

Parsons, Ruth J., James D. Jorgensen, Santos H. Hernandez, 1994. The Integration of Social Work Practice. Wadsworth, Inc., California

Raharjo, ST (ed). (2016). Kerentanan dan Disabilitas, Kumpulan Tulisan. Bandung: Unpad Press.

Raharjo, ST .(2015). Pekerjaan Sosial Generalis, Pengantar Bekerja Bersama Organisasi dan Komunitas. Bandung: Unpad Press.

Rappaport, J., 1984. Studies in Empowerment: Introduction to the Issue, Prevention In Human Issue. USA.

Rencana Pembangunan Jangka Menengah Desa 2011-2015. Desa Genteng, Kecamatan Sukasari, Kabupaten Sumedang. 2011.

Suharto. Edi.1997.Pembangunan, Kebijakan Sosial, dan Pekerjaan Sosial. Bandung: LSPSTKS

Wibhawa, B., Raharjo, ST., \& Santoso, MB. 2010. Dasar Dasar Pekerjaan Sosial. Widya Padjadjaran: Bandung 